\title{
RECENT DEVELOPMENTS IN DATING ANCIENT CRUSTAL FLUID FLOW
}

\author{
Alex N. Halliday, Matthias Ohr, Klaus Mezger, \\ John T. Chesley, Shun'ichi Nakai, and Charles P. DeWolf \\ Department of Geological Sciences \\ University of Michigan, Ann Arbor
}

\begin{abstract}
Several isotopic techniques have recently been developed or substantially improved, allowing the accurate determination of the timing of fluid-related processes. These include $\mathrm{K}-\mathrm{Ar}, \mathrm{Rb}-\mathrm{Sr}$, and $\mathrm{Sm}-\mathrm{Nd}$ dating of diagenetic minerals in clastic rocks, $\mathrm{U}-\mathrm{Pb}$ dating of carbonates, Sm-Nd dating of fluorite and uraninite, Re-Os
\end{abstract}

and $\mathrm{Rb}-\mathrm{Sr}$ dating of sulfides, ${ }^{40} \mathrm{Ar}-{ }^{39} \mathrm{Ar}$ and $\mathrm{Rb}-\mathrm{Sr}$ dating of fluid inclusions, and U-Pb dating of ilmenite/magnetite, sphene, and rutile. While many of these techniques require further evaluation, some have already resulted in new constraints on a variety of crustal fluid flow models.

\section{INTRODUCTION}

The movement of crustal fluids in the geological past is not easily studied, because the products of such activity generally preserve only partial evidence of the scale of circulation, origins of fluid, and mechanisms responsible for migration. Such fluid movement leads to the redistribution of significant amounts of certain components in the crust, including hydrocarbons [Burst, 1969], and the formation of economic concentrations of metals $(\mathrm{Cu}, \mathrm{Pb}$, $\mathrm{Zn}, \mathrm{U}$ ) and other raw materials (such as barite and fluorite) [Bethke, 1986; Bethke and Marshak, 1990; Sverjensky, 1986; Oliver, 1986; Duane and DeWit, 1988]. Fluids are of more fundamental significance than this, however, since they exercise a critical control on the processes of diagenesis, metamorphism, metasomatism, and melting. As such, the timing and scale of fluid movements in the crust are of interest to a far broader range of scientists than those concemed with economic geology per se.

Our understanding of large-scale crustal fluid flow has been hampered by the paucity of constraints on the timing and magnitude of migration and interaction. Radiogenic isotope geochemistry provides tracers to quantify the interaction between fluids and various crustal reservoirs as well as methods of dating the products of fluid flow. This paper is concerned with the latter of these two applications and attempts to point out both the potential and limitations of most of the new techniques, as applied to hydrothermal mineralization, diagenesis, and low-grade metamorphism $\left(<300^{\circ} \mathrm{C}\right)$.
The development of reliable geochronology for the growth of specific mineral phases in low-temperature environments has been slow for several reasons.

1. The number of minerals demonstrated to have suitable parent/daughter element ratios for precise geochronology was relatively small until recently.

2. Many of the processes of interest are recorded in mixtures of inherited assemblages formed at different times. As such these phases were not in isotopic or chemical equilibrium.

3. Several of the traditional techniques are subject to resetting or disturbance, particularly those involving metastable phases.

4. The development of some methods has required technical improvements in blanks and mass spectrometry.

As a direct consequence of these problems there has been a lack of tightly constrained models for the timing and ultimate cause of large-scale fluid movements. Furthermore, the complexity of the systems and ambiguity of some of the isotopic data that do exist have resulted in equivocal interpretations.

\section{GLOSSARY}

Blanks: Analytical backgrounds that must be corrected for or reduced to negligible levels in order for the data to truly represent the composition of the analyzed sample material.

Closure Temperature: Temperature below which diffusion of the radioactive and radiogenic nuclides is 
effectively negligible or, more strictly, the temperature that a slowly cooling mineral had at the time defined by its age [Dodson, 1973].

Diagenesis: Chemical and mineralogical changes in a sediment that take place after deposition including those involved in lithification, for example, compaction, loss of water, low-temperature recrystallization, and later replacement. The term is used by some in the context of processes that occur within a few million years of deposition but more broadly by others. It does not include metamorphic and metasomatic reactions.

Metasomatism: Chemical and, in some instances, mineralogical modification of rocks via medium- to high-temperature fluids.

\section{TRADITIONAL APPROACHES}

The major problem with traditional chronometers of crustal-scale fluid flow is that those which are most commonly deployed reset easily with mild heating $\left(<200^{\circ} \mathrm{C}\right)$, chemical exchange with hydrothermal fluids, or stress-activated recrystallization. For example, it has long been known that $\mathrm{K}-\mathrm{Ar}$ and ${ }^{40} \mathrm{Ar}-{ }^{39} \mathrm{Ar}$ dating of hydrothermal feldspars and clays suffer from the problem of low-temperature resetting [Halliday, 1977; Halliday and Mitchell, 1976, 1984]. While it is well established that these minerals retain argon at temperatures below $100^{\circ} \mathrm{C}$ [Ineson and Mitchell, 1972; Bonhomme et al., 1983; Aronson and Lee, 1986], it is doubtful that such minerals completely retain $\mathrm{Ar}$ for long periods at higher temperatures or in hydrothermal environments. If the thermal history is not well established, as for example in many older rocks, it will be difficult to discem whether clays and feldspars have lost Ar during burial and deformation (in the case of sedimentary rocks) or repeated hydrothermal activity (in the case of vein systems) and hence yield ages that merely date the last tectonic or thermal disturbance. Such a disturbance could be of interest and may correspond to fluid flow [Macintyre, 1986], but it is difficult to be certain whether the apparent ages correspond to the growth of the mineral, to later deformation or heating, or are geologically meaningless because of partial resetting.

A major problem with feldspars and clays is that there does not exist at this time a clear understanding of the transport paths for Ar loss and why some feldspars are more retentive than others. Some early models based on the assumption that the width of alkali feldspar exsolution lamellae defines the effective grain size for diffusion [Harrison and $B e ́, 1983$ ] have largely been superseded by models that consider argon loss properties to be dominated by submicroscopic pores and domain (or subgrain) boundaries [Parsons et al., 1988; Lovera et al., 1989; Kelley et al., 1989]. Certainly, evidence for fluid-related microcracks and micropores in feldspars is abundant [Montgomery and Brace, 1975; Rodgers and Holland,
1979; Worden et al., 1990; Walker, 1990] and presents a severe difficulty to those attempting to infer loss properties of feldspars in the low-temperature fluid-rich environments of diagenesis and hydrothermal activity.

Such ambiguities surround the often cited conclusion that widespread formation of K-feldspar overgrowths and illite in early Paleozoic sedimentary rocks in the Appalachians took place during the Alleghanian Orogeny at circa $300 \mathrm{Ma}$ [Hearn and Sutter, 1985; Hearn et al., 1987; Elliot and Aronson, 1987]. The data can also be interpreted in terms of partial resetting during burial and deformation [Craddock and van der Pluijm, 1989].

The ${ }^{40} \mathrm{Ar}-{ }^{39} \mathrm{Ar}$ dating of feldspars and $\mathrm{K}-\mathrm{Ar}$ dating of clays are clearly useful for studying thermal histories [Harrison and McDougall, 1982; Harrison and Be, 1983], for determining minimum ages and timing of hydrothermal overprinting [Halliday and Mitchell, 1984; Jackson et al., 1982], or for dating the growth of diagenetic minerals formed during or immediately following lithification in young sedimentary rocks for which a low-temperature $\left(<100^{\circ} \mathrm{C}\right)$ thermal history can be established with some confidence [Aronson and Hower, 1976; Aronson and Douthitt, 1986; Lee et al., 1989]. The most reliable K-Ar geochronology of ore deposits utilizes ${ }^{40} \mathrm{Ar}-{ }^{39} \mathrm{Ar}$ dating of coarsely crystallized micas [Snee et al., 1988], combines the data with $\mathrm{Rb}-\mathrm{Sr}$ studies of the same minerals [Jackson et al., 1982; Böhlke and Kistler, 1986], or is undertaken on a variety of different minerals in a young setting [Bethke et al., 1976].

The U-Th- $\mathrm{Pb}$ dating of fine-grained $\mathrm{U}$ and $\mathrm{Th}$ rich minerals such as pitchblende and coffinite can suffer analogous problems of $\mathrm{Pb}$ loss, although it may be possible to discern the original history from the $\mathrm{Pb}$ isotopic compositions [Stuckless et al., 1979; Cunningham et al., 1982; Ludwig et al., 1984; Hon et al., 1985].

Model ages offer another rather limited approach in which an "age" is calculated assuming a specific source for the components (hence initial isotopic composition). Such approaches have been used for $\mathrm{Pb}, \mathrm{Sr}$, and $\mathrm{Nd}$ isotopic ages [Godwin and Sinclair, 1982; Ruiz et al., 1984; Kesler et al., 1988; Halliday et al., 1986, 1990]. However, in many situations the source of components is poorly constrained, and as a consequence, the results are dependent on the model chosen. Even if source reservoirs have been characterized in detail, it needs to be established that the fluids equilibrated isotopically with the bulk lithologies rather than with a select assemblage of minerals that were more susceptible to leaching and reaction with the fluids [Halliday et al., 1990].

\section{NEW APPROACHES}

The most promising new techniques generally involve small samples, necessitating low blanks and highsensitivity mass spectrometry but utilize decay systems 
that have been studied for some time including ${ }^{87} \mathrm{Rb}-{ }^{87} \mathrm{Sr}$, ${ }^{147} \mathrm{Sm}_{-}{ }^{143} \mathrm{Nd},{ }^{40} \mathrm{~K}\left({ }^{39} \mathrm{Ar}\right)-{ }^{40} \mathrm{Ar}$, ${ }^{238} \mathrm{U}-{ }^{206} \mathrm{~Pb}$, and ${ }^{187} \mathrm{Re}-$ ${ }^{187}$ Os.

Of these the ${ }^{187} \mathrm{Re}-{ }^{187}$ Os system has been least studied because of difficulties with the chemical preparation and the ionization of Os, traditionally tackled using secondary ionization or resonance ionization mass spectrometry. It has recently been shown that Os isotopic compositions can be determined relatively simply and at much higher sensitivity using negative thermal ionization mass spectrometry [Creaser et al., 1991]. This has greatly helped to pave the way for a variety of interesting new studies using Os isotope geochemistry. Reconnaissance studies of hydrothermal ores and clastic sediments [Luck and Allegre, 1982; Ravizza and Turekian, 1989; Walker et al., 1989] indicate considerable fractionation of $\mathrm{Re} / \mathrm{Os}$ ratios in fluid-related crustal processes and precipitation of sulfides, offering potential as a chronometer of crustal fluid flow.

Even though the uses of the other decay schemes have been appraised more fully, the most exciting developments with respect to dating crustal fluid flow are still in their infancy and need to be evaluated carefully on a mineralby-mineral basis, to determine the closure temperatures and general robustness to resetting. In all of these systems it is critical that the ratio of the parent element to the daughter element should be relatively high and/or display a considerable range among a cogenetic suite of minerals and that the amount of radiogenic daughter isotope should be high relative to background levels (be they "common" inherited components or analytical blank).

In many of the techniques that we now discuss the exact host of the parent and daughter elements and the factors controlling the fractionation of parent/daughter ratio are ill defined. This is because a number of the new techniques utilize host minerals into which the radioactive parent element does not readily substitute. For many of these it is far from obvious whether the parent element is hosted in defects, strained sites, or submicroscopic inclusions of some minor phase, distinct from the major host mineral. It is then even more difficult to assess what factors are controlling the parent/daughter ratios. In certain instances this may be of little consequence, but in low-temperature nonequilibrium environments it is critical to know which phase and process in the potentially complex, multistage history is being dated.

\section{Dating Diagenesis}

K-Ar dating of illite and diagenetic K-feldspar overgrowths have been used very effectively to date the diagenesis of clastic sediments and migration of hydrocarbons in young sedimentary basins [Lee et al., 1985, 1989; Liewig et al., 1987; Girard et al., 1988; Hamilton et al., 1989; Burley and Flisch, 1988]. Laser probe ${ }^{40} \mathrm{Ar}-{ }^{39} \mathrm{Ar}$ dating of clastic diagenesis, as first illustrated by the work of York and Hall [1986], has been surprisingly slow to develop. Kelley et al. [1989] report the presence of a component of excess argon in alkali feldspars which can be degassed easily by mild heating at low temperatures but otherwise results in meaningless total degassing ages using a pulsed laser. These effects need to be carefully evaluated before further progress can be made.

Some recent studies of fluid-induced clay diagenesis in clastic sedimentary sequences have highlighted the potential usefulness of $\mathrm{Rb}$-Sr dating of authigenic illite, provided great care is exercised in eliminating older mineral grains that were part of the original sedimentary detritus and removing nonradiogenic $\mathrm{Sr}$ by acid leaching [Clauer, 1976, 1979, 1982; Chauduri and Brookins, 1979; Ohr et al., 1991]. A more controversial approach has been to use the combined $\mathrm{Rb}-\mathrm{Sr}$ data for the leachate and for the residue from leaching, to define the age of illite growth [Erwin and Long, 1989], assuming that exchangeable Sr has not reequilibrated with later pore fluids since crystallization of the illite. In certain cases it can be shown that such late reequilibration has in fact occurred and such ages would be meaningless [Ohr et al., 1991]. In contrast, the residues from leaching of fine-grained clay fractions (assumed to be pure diagenetic illite) commonly display a reasonable spread in $\mathrm{Rb} / \mathrm{Sr}$ (possibly inherited from the rock-dominated pore fluid). The $\mathrm{Rb}-\mathrm{Sr}$ isotopic data for such leached diagenetic clays sampled over a considerable depth range $(>1,000 \mathrm{~m})$ can define an apparent isochron, thought to define the age of growth of the authigenic illite. Results obtained in this manner have been interpreted in terms of simultaneous fluid movement over several thousand meters of sediment [Morton, 1985a, b; Ohr et al., 1991].

There are some critical questions to be addressed in this type of work. For example, what exactly is happening to the clay grains during the leaching procedure? Is "exchangeable $\mathrm{Sr}^{2}$ " absorbed in some way on the clay surfaces or does it represent submicroscopic growth of soluble low-temperature phases? Is the exchangeable $\mathrm{Sr}$ irrelevant or does it record an important aspect of the fluid-mineral interaction history? What controls the variations in $\mathrm{Rb} / \mathrm{Sr}$ in the leached residues of fine-grained authigenic illite; is it protolith variations in $\mathrm{Rb} / \mathrm{Sr}$ ? If so, there must surely be some heterogeneity in initial ${ }^{87} \mathrm{Sr} /{ }^{86} \mathrm{Sr}$ in such a rock-dominated diagenetic system. Despite considerable efforts, these important aspects remain largely unresolved.

Awwiller and Mack [1989, 1991] have argued that $\mathrm{Sm} / \mathrm{Nd}$ can be fractionated during diagenesis of finegrained clastic sediment. This has been confirmed by the findings of Ohr and Halliday [1990] who have shown that leaching of fine-grained authigenic illite fractions from clastic sediments produces a leachable component with high $\mathrm{Sm} / \mathrm{Nd}$, in apparent isotopic equilibrium with nonleachable diagenetic illite with low $\mathrm{Sm} / \mathrm{Nd}$ at the time of diagenesis. In this respect, the commonly held assumption that the rare earth elements are immobile in clastic 
diagenesis is clearly incorrect. Research on Paleozoic low-grade metasediments from the Appalachians and the Welsh Basin indicate that it may be possible to date fluid equilibration in older clastic rocks using such a single sample approach [Ohr and Halliday, 1990]. Again, the questions of what the leachable component represents and the mechanisms of $\mathrm{Sm} / \mathrm{Nd}$ fractionation need to be addressed. In this respect, it is important to determine the chemical composition of the leachates and examine the mineral separates before and after leaching using scanning transmission electron microscopy. There is, however, a clear advantage of single sample Sm-Nd leachate-residue ages over the Rb-Sr isochron approach, namely that the effect of provenance variations can be eliminated.

In recent years the $\mathrm{U}-\mathrm{Pb}$ and $\mathrm{Pb}-\mathrm{Pb}$ methods have found increasing application in the dating of marine carbonates and their metamorphosed equivalents [Moorbath et al., 1987; Jahn, 1988; Smith and Farquhar, 1988; DeWolf and Halliday, 1989; Jahn et al., 1990]. The high U/Pb commonly found in such rocks is partly a reflection of the high $\mathrm{U} / \mathrm{Pb}$ of seawater. However, high $\mathrm{U} / \mathrm{Pb}$ has also been found in secondary dolomites [Hoff and Jameson, 1989], and U-Pb dating of secondary carbonates associated with late fluid movements in limestones and hydrothermal vein systems may be possible. U-Pb dating of limestones appears to be a relatively robust technique that may record the time of early diagenesis [DeWolf and Halliday, 1991] even when the rocks have been disturbed. For example, the Paleozoic limestones of New York State acquired a secondary chemical magnetization supposedly caused by pervasive fluid flow during the Alleghanian Orogeny [Wisniowiecke, 1983; Jackson et al., 1988; Van der Voo, 1989] yet display no sign of this disturbance in the U-Pb systematics of the calcites [DeWolf and Halliday, 1989]. The mechanisms of $U$ incorporation are not well understood, and it may be a late process [Hoff and Hanson, 1990]. Chung and Swart [1990] have suggested that variations in $U$ concentration in carbonates may result from changes in the $\mathrm{CO}_{2}$ of the fluid, together with selective exclusion of $U$ during precipitation of calcite.

$\mathrm{U}-\mathrm{Pb}$ techniques have also been applied to hydrocarbons themselves Parnell and Swainbank, 1990], and the direct dating of oil formation or accumulation may be possible in the near future.

\section{Dating Mineralization}

The Rb-Sr method has been successfully applied to hydrothermal phases such as low-temperature K-rich alkali feldspar with high $\mathrm{Rb} / \mathrm{Sr}$, fine-grained muscovites, and sulfides [Halliday, 1980; Jackson et al., 1982; Nakai et al., 1990; Brannon et al., 1991]. In the case of sulfides it is unclear where the small amounts $(<1 \mathrm{ppm})$ of $\mathrm{Rb}$ and $\mathrm{Sr}$ are located and what exact mechanism produces the range in $\mathrm{Rb} / \mathrm{Sr}$. Nonetheless, the method scems to permit the determining of ages of otherwise undateable hydrothermal assemblages such as Mississippi Valley type (MVT) mineralization. The results obtained so far are interesting since the major MVT mineralization in the eastern United States appears to have taken place at circa $380 \mathrm{Ma}$ [Nakai et al., 1990] and therefore cannot be related to large-scale fluid flow during the Alleghanian Orogeny at $300 \mathrm{Ma}$ [Oliver, 1986; Miller and Kent, 1988].

A potentially very promising technique is the application of Sm-Nd dating to hydrothermal assemblages that fractionate rare earth elements (REE) strongly [Moller et al., 1976; McLennan and Taylor, 1979; Alderton et al., 1980; Morgan and Wandless, 1980; Graf, 1984; Humphris, 1984]. The mechanisms of REE fractionation appear to be variable and are in some instances poorly understood. Complexing involving volatile phases such as $\mathrm{CO}_{2}, \mathrm{Cl}$, and $\mathrm{F}$ could potentially play a role, as well as middle REE substitutions into $\mathrm{Ca}$ minerals such as $\mathrm{CaF}_{2}$ (fluorite). In addition, the precipitation of REE-enriched phases in hydrothermal systems can lead to marked changes in $\mathrm{Sm} / \mathrm{Nd}$ in the fluid. Sm-Nd dating has been applied to heavy REE enriched uraninites [Fryer and Taylor, 1984], scheelites [Bell et al., 1989], and fluorites [Chernyshev et al., 1986; Halliday et al., 1986, 1990; Chesley et al., 1991]. Sm/Nd in fluorite can vary by as much as an order of magnitude in an individual mineral vein, permitting precise $( \pm 1 \%)$ isochron ages [Chesley et al., 1991]. This technique may be useful for determining the ages of fluorite-bearing MVT deposits.

Another powerful approach has been to study fluid inclusions in quartz with $\mathrm{Rb}-\mathrm{Sr}, \mathrm{U}-\mathrm{Pb}$, and ${ }^{40} \mathrm{Ar}-{ }^{39} \mathrm{Ar}$ methods. Rb-Sr dating by total dissolution of quartz, in which it is assumed that the $\mathbf{R b}$ and $\mathrm{Sr}$ are held in fluid inclusions, has been highly successful [Powers et al., 1979; Shepherd and Darbyshire, 1981; Shepherd et al., 1982; Shepherd, 1986; Darbyshire and Shepherd, 1987]. Similar approaches have been adopted by Hemming et al. [1990] utilizing the U-Pb technique. All of these studies are useful but suffer from the uncertainty in the location of the $\mathrm{Rb}, \mathrm{Sr}, \mathrm{U}$, or $\mathrm{Pb}$ (fluid inclusion, solid inclusion, or host mineral). This may not be a problem if the fluids and host are truly co-genetic, but if the fluid inclusions are wholly or in part unrelated to the growth of the quartz (as is commonly thought to be the case), the isotopic ages may date this later process. Relatively little work has been done on extracted fluids, and that which exists does not distinguish separate populations of fluid inclusions [Norman, 1978; Norman and Landis, 1983; Changkakoti et al., 1988]. It may prove possible to separate individual generations of fluid inclusions, but this is not a trivial task. For many kinds of fluid inclusions the difficulty of this extraction process is the limiting factor rather than blank or machine sensitivity.

The ${ }^{40} \mathrm{Ar}-{ }^{39} \mathrm{Ar}$ dating of fluid inclusions has developed slowly over the past few years [Kelley et al., 1986; Böhlke et al. 1987; Kirschbaum et al., 1987; Turner, 1988]. Turner [1988] shows how, using correlation plots, the different Ar components (radiogenic, atmospheric, 
extraneous) can be deciphered in such materials. As with all of the fluid inclusion techniques, there is the limitation of measuring unknown mixtures of different generations of inclusion fluids, unless the inclusions are of sufficient size and age that they can be analyzed on an individual basis with laser methods.

Some of the most impressive geochronology of hydrothermal ore deposits utilizes the power of the ${ }^{40} \mathrm{Ar}-{ }^{39} \mathrm{Ar}$ dating technique for precise resolution of small age differences. Snee et al. [1988] report a resolution of $0.3 \%$ in ${ }^{40} \mathrm{Ar}-{ }^{39} \mathrm{Ar}$ ages of mica populations from Panasqueira, Portugal. The use of the laser probe ${ }^{40} \mathrm{Ar}-{ }^{39} \mathrm{Ar}$ method for dating different phases in hydrothermal mineral assemblages has so far been barely explored [York et al., 1982; Sutter et al., 1983; Hall et al., 1989] but offers exciting possibilities for future research.

Some of the chronometers that have been developed for studying high-grade metamorphism may prove ideal for the dating of other, more demonstrative products of crustal-scale fluid flow. These new chronometers include Sm-Nd, Rb-Sr, and U-Pb dating of garnet [Cohen et al., 1988; Christensen et al., 1989; Mezger et al., 1989a; Vance and O'Nions, 1990] and U-Pb dating of sphene [Tucker et al., 1987], monazite [Copeland et al., 1989], rutile [Mezger et al., 1989b], and ilmenite/magnetite [Burton and O'Nions, 1990]. Corfu and Muir [1989] showed that Precambrian gold mineralization could be dated using accessory phases that grew from the hydrothermal fluids. Similarly, Schandl et al. [1990] utilized hydrothermal rutile to date sulfide deposition and associated alteration. Finally, Zeitler et al. [1990] have been able to deduce the timing of fluid flow in the formation of quartz-graphite veins by $\mathrm{U}-\mathrm{Pb}$ ion microprobe dating of zircon overgrowths.

Accessory mineral U-Pb chronometers are in some respects superior to all others, since they can give very high precision $( \pm 0.1 \%)$ ages, and neither reset readily nor suffer from the assumptions of isotopic equilibrium critical to the isochron approach. In addition, with the utilization of ion probe techniques they may be especially useful for placing the detailed mineral parageneses into a framework of absolute time.

\section{CONCLUSION}

The new technique developments in isotope geochemistry over the past 5 years have facilitated the accurate dating of a wide range of fluid-related assemblages and have opened up new possibilities for constraining models of relevant geological processes such as diagenesis, brine migration, mineralization, and hydrocarbon emplacement. The major advances have been in the application of the Rb-Sr, U-Pb, and Sm-Nd systems to new phases in which significant fractionations of the parent/daughter ratio have recently been discovered. These methods complement traditional approaches, some of which are more appropriately used to define thermal histories or date the last significant thermal or tectonic event. The major developments needed include integrated isotopic, chemical, and mineralogical studies of the same geological problem. For example, dating clastic diagenesis could involve combined $\mathrm{Rb}-\mathrm{Sr}, \mathrm{Sm}-\mathrm{Nd}$, and $\mathrm{K}-\mathrm{Ar}$ dating studies of authigenic illite and associated phases, in which the chemical compositions of leachates are fully determined, and mineral separates and leachate residues are characterized using scanning transmission electron microscopy. More exploratory work is needed and anticipated, specifically with low-temperature applications of $\mathrm{Re}-\mathrm{Os}, \mathrm{Sm}-\mathrm{Nd}$ dating of diagenesis, U-Pb dating of hydrocarbons, and ${ }^{40} \mathrm{Ar}-{ }^{39} \mathrm{Ar}$ and U-Pb dating of hydrothermal and diagenetic phases. Major problems remain with our understanding of the location of radioactive parents in some of the phases of interest, the factors controlling parent/daughter ratios, and the effects of acid leaching. Finally, new techniques are needed for separating phases of interest at the microscopic and submicroscopic scale, especially fluid inclusions from their host minerals. Further applications may involve broad-scale integrated approaches using a variety of isotopic methods to study large crustal sections and determine the ages of fluid expulsion from sediments, mineral overgrowths in aquifers, hydrocarbon migration, and base metal mineralization and hence assess the relationships between these diverse products of crustal fluid flow. With such information it should be possible to formulate dynamic models of crustal fluid flow that are considerably more reliable than has hitherto been the case.

ACKNOWLEDGMENTS. Radiogenic isotopic studies of crustal-scale fluid flow at the University of Michigan have been supported from NSF grants EAR 86-16061, 88-04072, 88-05083, 90-04413, and 90-05516. We are grateful to Bob Bodnar, Paul Dixon, Eric Essene, Lynton Land, Mack Kennedy, Steve Kesler, Don Peacor, Rob Van der Voo, Peter Vrolijk, Lynn Walter, Bruce Wilkinson, and many others for discussion.

H. Jay Melosh and Marcia Neugebauer were the editors responsible for this paper. They thank Lynton Land and an anonymous referee for their help in evaluating this paper.

\section{REFERENCES}

Alderton, D. H. M., J. S. Pearce, and P. J. Potts, Rare earth element mobility during granite alteration: Evidence from southwest England, Earth Planet. Sci. Lett., 49, 149-165, 1980.

Aronson, J. L., and C. B. Douthitt, K/Ar systematics of an acid-treated illite/smectite: Implications for evaluating age and crystal structure, Clays Clay Miner., 34, 473-482, 1986.

Aronson, J. L., and J. Hower, Mechanism of burial metamorphism of argillaceous sediment, 2, Radiogenic argon evidence, Geol. Soc. Am. Bull., 87, 738-744, 1976.

Aronson, J. L., and M. Lee, K/Ar systematics of bentonite and shale in contact metamorphic zone, Cerrillos, New Mexico, Clays Clay Miner., 34, 483-487, 1986. 
Awwiller, D. N., and L. E. Mack, Diagenetic resetting of Sm-Nd isotope systematics in Wilcox Group sandstones and shales, San Marcos Arch, south-central Texas, Gulf Coast Assoc. Geol. Soc. Trans., 39, 321-330, 1989.

Awwiller, D. N., and L. E. Mack, Diagenetic modification of Sm-Nd model ages in Tertiary sandstones and shales, Texas Gulf Coast, Geology, 19, 311-314, 1991.

Bell, K., C. D. Anglin, and J. M. Franklin, Sm-Nd and Rb-Sr isotope systematics of scheelites: Possible implications for the age and genesis of vein-hosted gold deposits, Geology, 17, 500-504, 1989.

Bethke, C. M., Hydrologic constraints on the genesis of upper Mississippi valley mineral district from Illinois Basin brines, Econ. Geol., 81, 233-249, 1986.

Bethke, C. M., and S. Marshak, Brine migrations across North America-The plate tectonics of groundwater, Ann. Rev. Earth Planet. Sci., 18, 287-315, 1990.

Bethke, P. M., P. B. Barton, Jr., M. A. Lanphere, and T. A. Steven, Environment of ore deposition in the Creede mining district, San Juan Mountains, Colorado: Age of mineralization, Econ Geol., 71, 1006-1011, 1976.

Böhlke, J. K., and R. W. Kistler, Rb-Sr, K-Ar and stable isotope evidence for the ages and sources of fluid components of gold-bearing quartz veins in the Northern Sierra Nevada Foothills Metamorphic Belt, Califomia, Econ. Geol., 81, 296-322, 1986.

Böhlke, J. K., C. Kirschbaum, J. J. Irwin, and W. E. Glassely, Laser microprobe analyses of noble gas isotopes in fluid inclusions in neutron-irradiated quartz veins, Geol. Soc. Am. Abstr. Programs, 19, 594, 1987.

Bonhomme, M. G., D. Buhmann, and Y. Besnus, Reliability of $\mathrm{K}-\mathrm{Ar}$ dating of clays and silicifications associated with vein mineralizations in Westem Europe, Geol. Rundsch., 72, 105-117, 1983.

Brannon, J. C., F. A. Podosek, J. G. Viets, D. L. Leach, M. Goldhaber, and E. L. Rowan, Strontium isotopic constraints on the origin of ore forming fluids of the Vibumum Trend, southeast Missouri, Geochim. Cosmochim. Acta, 55, 1407-1419, 1991.

Burley, S. D., and M. Flisch, K-Ar geochronology and the timing of detrital I/S clay illitization and authigenic illite precipitation in the Piper and Tartan Fields, Outer Moray Firth, UK North Sea, Clay Miner., 24, 285-315, 1989.

Burst, J. F., Diagenesis of Gulf Coast clayey sediments and its possible relation to petroleum migration, Bull Am. Assoc. Petrol. Geol., 53, 73-93, 1969.

Burton, K. W., and R. K. O'Nions, Fe-Ti oxide chronometry: With application to granulite formation, Geochim. Cosmochim. Acta, 54, 2593-2602, 1990.

Changkakoti, A., J. Gray, D. Kristic, G. L. Cumming, and R. D. Morton, Determinations of radiogenic isotopes ( $\mathrm{Rb} / \mathrm{Sr}$, $\mathrm{Sm} / \mathrm{Nd}$, and $\mathrm{Pb} / \mathrm{Pb}$ ) in fluid inclusion waters: An example from the Bluebell $\mathrm{Pb}-\mathrm{Zn}$ deposit, British Columbia, Canada, Geochim. Cosmochim. Acta, 52, 961-967, 1988.

Chauduri, S., and D. G. Brookins, The Rb-Sr systematics in acid leached clay minerals, Chem. Geol., 24, 231-242, 1979.

Cherneyshev, I.V., V. A. Troitsky, and D. Z. Zhuravlev, Pb, Sr and $\mathrm{Nd}$ isotopes in minerals of tungsten deposits, Terra Cognita, 6, 226-227, 1986.

Chesley, J. T., A. N. Halliday, and R. C. Scrivener, Sm-Nd direct dating of fluorite mineralization, Science, 252, 949-951, 1991.

Christensen, J. N., J. L. Rosenfeld, and D. J. DePaolo, Rates of tectonometamorphic processes from rubidium and strontium isotopes in garnet, Science, 244, 1465-1469, 1989.

Chung, G. S., and P. K. Swart, The concentration of uranium in freshwater vadose and phreatic cements in a Holocene ooid clay: A method of identifying ancient water tables, $J$. Sediment Petrol., 60, 735-746, 1990.

Clauer, N., Geochimie isotipique du Strontium des milieux sedimentaires, Mem. Sci. Geol., 45, 256 pp., 1976.

Clauer, N., A new approach to Rb-Sr dating of sedimentary rocks, in Lectures in Isotope Geology, edited by E. Jaeger and J. C. Hunziker, pp. 30-51, Springer-Verlag, New York, 1979.

Clauer, N., The Rb-Sr method applied to sediments: Certitudes and uncertainties, in Numerical Dating Methods in Stratigraphy, edited by G. S. Odin, pp. 245-276, John Wiley, New York, 1982.

Cohen, A. S., R. K. O'Nions, R. Siegenthaler, and W. L. Griffin, Chronology of the pressure-temperature history recorded by a granulite terrain, Contrib. Mineral. Petrol., 98, 303-311, 1988.

Copeland, P., R. R. Parrish, and T. M. Harrison, Identification of inherited radiogenic $\mathrm{Pb}$ in monazite and its implications for U.Pb systematics, Nature, 333, 760-763, 1988.

Corfu, F., and T. L. Muir, The Hemlo-Heron Bay greenstone belt and Hemlo Au-Mo deposit, Superior Province, Ontario, Canada, 2, Timing of metamorphism, alteration and $\mathrm{Au}$ mineralization from titanite, rutile, and monazite $\mathrm{U}-\mathrm{Pb}$ geochronology, Chem. Geol., 79, 201-223, 1989.

Craddock, J. P., and B. A. van der Pluijm, Late Paleozoic deformation of the cratonic carbonate cover of eastern North America, Geology, 17, 416-419, 1989.

Creaser, R. A., D. A. Papanastassiou, and G. J. Wasserburg, Negative thermal ion mass spectrometry of osmium, rhenium and iridium, Geochim. Cosmochim. Acta, 55, 397-401, 1991.

Cunningham, C. G., K. R. Ludwig, C. W. Naeser, E. K. Weiland, H. H. Mehnert, T. A. Steven, and J. D. Rasmussen, Geochronology of hydrothermal uranium deposits and associated igneous rocks in the eastem source area of the Mount Belknap volcanics, Marysvale, Utah, Econ. Geol., 77, 453-463, 1982.

Darbyshire, D. P. F., and T. J. Shepherd, Chronology of granite magmatism and associated mineralization, S. W. England, $J$. Geol. Soc. London, 142, 1159-1177, 1987.

DeWolf, C. P., and A. N. Halliday, Whole rock U-Pb dating of Paleozoic limestones (abstract), Eos Trans. AGU, 70, 1148, 1989.

DeWolf, C. P., and A. N. Halliday, U-Pb dating of a remagnitized Paleozoic limestone, Geophys. Res. Lett., in press, 1991.

Dodson, M. H., Closure temperature in cooling geochronological and petrological systems, Contrib. Mineral. Petrol., 40, 259-274, 1973.

Duane, M. J., and M. J. DeWit, $\mathrm{Pb}-\mathrm{Zn}$ ore deposits of the northem Caledonides: Products of continental scale fluid mixing and tectonic expulsion during continental collision, Geology, 16, 99-1002, 1988.

Elliott, W. C., and J. L. Aronson, Alleghanian episode of K-bentonite illitization in the southern Appalachian Basin, Geology, 15, 735-739, 1987.

Erwin, M. E., and L. E. Long, Rb-Sr ages of diagenesis of Mg-rich clay, Permian evaporite sequence, Palo Duro Basin, Geol. Soc. Am. Abstr. Programs, 21, A-17, 1989.

Fryer, B. J., and R. P. Taylor, Sm-Nd direct dating of the Collins Bay hydrothermal uranium deposit, Saskatchewan, Geology, $12,479-482,1984$.

Girard, J-P., J. L. Aronson, and S. M. Savin, Separation, K/Ar dating and ${ }^{18} \mathrm{O} /{ }^{16} \mathrm{O}$ ratio measurements of diagenetic K-feldspar overgrowths: An example from the Lower Cretaceous arkoses of the Angola Margin, Geochim. Cosmochim. Acta, 52, 2207-2214, 1988.

Godwin, C. I., and A. J. Sinclair, Average lead isotope growth curves for shale-hosted zinc-lead deposits, Canadian Cordillera, Econ. Geol., 77, 675-690, 1982. 
Graf, J. L., Jr., Effects of Mississippi Valley-type mineralisation on REE patterns of carbonate rocks and minerals, Viburnum trend, S.E. Missouri, J. Geol., 92, 307-324, 1984.

Hall, C. M., D. York, C. M. Saunders, and D. F. Strong, Laser ${ }^{40} \mathrm{Ar}-{ }^{39} \mathrm{Ar}$ dating of Mississippi Valley Type mineralization from westem Newfoundland, Proc. Int. Geol. Congr., 2, 10-11, 1989.

Halliday, A. N., K-Ar dating of mineralisation episodes-A discussion, Econ. Geol., 72, 870-871, 1977.

Halliday, A. N., The timing of early and main stage ore mineralisation in S. W. Cornwall, Econ. Geol., 75, 752-759, 1980.

Halliday, A. N., and J. G. Mitchell, Structural, K-Ar and ${ }^{40} \mathrm{Ar}-{ }^{39} \mathrm{Ar}$ age studies of adularia K-feldspars from the Lizard Complex, England, Earth Planet. Sci. Lett., 29, 227-237, 1976

Halliday, A. N., and J. G. Mitchell, K-Ar ages of clay-size concentrates from the mineralisation of the Pedroches Batholith, Spain and evidence for Mesozoic hydrothermal activity associated with the break-up of Pangaea, Earth Planet. Sci. Lett., 68, 229-239, 1984.

Halliday, A. N., T. J. Shepherd, A. P. Dickin, F. MacLaren, and D. F. Darbyshire, Sm-Nd dating and fingerprinting of the North Pennine fluorite deposits, Terra Cognita, 6, 227, 1986.

Halliday, A. N., T. J. Shepherd, A. P. Dickin, and J. T. Chesley, $\mathrm{Sm}-\mathrm{Nd}$ evidence for the age and origin of a Mississippi Valley Type ore deposit, Nature, 344, 54-56, 1990.

Hamilton, P. J., S. Kelley, and A. E. Fallick, K-Ar dating of illite in hydrocarbon reservoirs, Clay Miner., 24, 215-231, 1989.

Harrison, T. M., and K. Bé, ${ }^{40} \mathrm{Ar}-{ }^{39} \mathrm{Ar}$ age spectrum analysis of detrital microclines from the southern San Joaquin Basin, Califomia: An approach to determining the thermal evolution of sedimentary basins, Earth Planet. Sci. Lett., 64, 244-256, 1983.

Harrison, T. M., and I. McDougall, The thermal significance of potassium feldspar K-Ar ages inferred from ${ }^{40} \mathrm{Ar}-{ }^{39} \mathrm{Ar}$ age spectrum results, Geochim. Cosmochim. Acta, 46, 1811-1820, 1982.

Hearn, P. P., and J. F. Sutter, Authigenic potassium feldspar in Cambrian carbonates: Evidence of Alleghenian brine migration, Science, 228, 1529-1531, 1985.

Hearn, P. P. Jr., J. F. Sutter, and H. E. Belkin, Evidence for Late-Paleozoic brine migration in Cambrian carbonate rocks of the central and southern Appalachians: Implications for Mississippi Valley-type sulfide mineralization, Geochim. Cosmochim. Acta, 51, 1323-1334, 1987.

Hemming, S., S. M. McLennan, G. N. Hanson, E. J. Krogstad, and $\mathrm{K}$. Mezger, $\mathrm{Pb}$ isotope systematics in quarts, (abstract), Eos Trans. $A G U, 71,654,1990$.

Hoff, J. A., and G. N. Hanson, Application of the $\mathrm{Pb}$ isotope system to carbonate diagenesis: Geochronologic and tracer studies, Geol. Soc. Am. Abstr. Programs, 22, 162, 1989.

Hoff, J. A., and J. Jameson, Timing of uranium enrichment in dolostones from the Wahoo Formation, subsurface, Prudhoe Bay, Alaska, Geol. Soc. Am. Abstr. Programs, 22, 16, 1989.

Hon, K., K. R. Ludwig, K. R. Simmons, J. F. Slack, and R. I. Grauch, $\mathrm{U}-\mathrm{Pb}$ isochron age and $\mathrm{Pb}$ isotope systematics of the Golden fleece vein-Implications for the relationship of mineralization of the Lake City Caldera, westem San Juans, Colorado, Econ. Geol., 80, 410-417, 1985.

Humphris, S. E., The mobility of the rare earth elements in the crust, in Rare Earth Element Geochemistry, edited by P. Henderson, pp. 317-342, Elsevier, New York, 1984.

Ineson, P. R., and J. G. Mitchell, Isotopic age determinations on clay minerals from lavas and tuffs of the Derbyshire orefield, Geol. Mag., 109, 501-512, 1972.
Jackson, N. J., A. N. Halliday, S. M. F. Sheppard, and J. G. Mitchell, Hydrothermal activity in the St. Just mining district, Cornwall, England, in Metallisation Associated with Acid Magmatism, edited by A. M. Evans, pp. 137-179, John Wiley, New York, 1982.

Jackson, M., C. McCabe, M. M. Ballard, and R. Van der Voo, Magnetite authigenesis and diagenetic paleotemperatures across the northem Appalachian basin, Geology, 16, 592-595, 1988.

Jahn, $\mathrm{B} ., \mathrm{Pb}-\mathrm{Pb}$ dating of young marbles from Taiwan, Nature, $332,429-432,1988$.

Jahn, B., J. Bertrand-Sarfati, N. Morin, and J. Macé, Direct dating of stromatolitic carbonates from the Schmidtsdrif Formation (Transvaal Dolomite), South Africa, with implications on the age of the Ventersdorp Supergroup, Geology, 18, 1211-1214, 1990.

Kelley, S., G. Turner, A. W. Butterfield, and T. J. Shepherd, The source and significance of argon isotopes in fluid inclusions from areas of mineralization, Earth Planet. Sci. Lett., 79, 303-318, 1986.

Kelley, S., I. Parsons, R. H. Worden, and D. L. Walker, A laser-probe study of argon-loss by alkali feldspars, with applications to thermal modelling, Eos Trans. AGU, 70, 1404-1405, 1989.

Kesler, S. E., L. M. Jones, and J. Ruiz, Strontium isotopic geochemistry of Mississippi Valley-Type deposits, East Tennessee: Implications for age and source of mineralizing brines, Geol. Soc. Am. Bull., 100, 1300-1307, 1988.

Kirschbaum, C., J. J. Irwin, J. K. Böhlke, and W. E. Glassley, Simultaneous analysis of halogens and noble gases in fluid inclusions in neutron-irradiated quartz veins: $A$ laser microprobe study, (abstract), Eos Trans. AGU, 68, 1514, 1987.

Lee, M. L., J. L. Aronson, and S. M. Savin, K-Ar dating of time of gas emplacement in Rotliegendes Sandstone, Netherlands, Bull. Am. Assoc. Petrol. Geol., 69, 1381-1385, 1985.

Lee, M. L., J. L. Aronson, and S. M. Savin, Timing and conditions of Permian Rotliegende Sandstone diagenesis, southem North Sea: K-Ar and oxygen isotopic data, Bull. Am. Assoc. Petrol. Geol., 73, 195-215, 1989.

Liewig, N., N. Clauer, and F. Sommer, Rb-Sr and K-Ar dating of clay diagenesis in Jurassic sandstone oil reservoir, North Sea, Bull. Am. Assoc. Petrol. Geol., 71, 1467-1474, 1987.

Lovera, O. M., F. M. Richter, and T. M. Harrison, The ${ }^{40} \mathrm{Ar}{ }^{\beta 9} \mathrm{Ar}$ thermochronometry for slowly cooled samples having a distribution of diffusion domain sizes, J. Geophys. Res., 94, 17,917-17,935, 1989.

Luck, J. M., and C. J. Allègre, The study of molybdenites through the ${ }^{187} \mathrm{Re}-{ }^{187}$ Os chronometer, Earth Planet Sci. Lett., 61, 291-296, 1982.

Ludwig, K. R., and J. A. Cooper, Geochronology of Precambrian granites and associated U-Ti-Th mineralization northem Olary province, South Australia, Contrib. Mineral. Petrol., 86, 298-308, 1984.

Macintyre, R. M., K-Ar ages and MVT deposits, Terra Cognita, 6, 227, 1986.

McLennan, S. M., and S. R. Taylor, Rare earth elements mobility associated with uranium mineralisation, Nature, 282, 247-250, 1979.

Mezger, K., G. N. Hanson, and S. R. Bohlen, U-Pb systematics of garnet: Dating the growth of garnet in the Late Archean Pikwitonei granulite domain at Cauchon and Natawahunan Lakes, Manitoba, Canada, Contrib. Mineral. Petrol., 101, 136-148, 1989a.

Mezger, K., G. N. Hanson, and S. R. Bohlen, High-precision $\mathrm{U}-\mathrm{Pb}$ ages of metamorphic rutile: Application to the cooling history of high-grade terranes, Earth Planet. Sci. Lett., 96, $106-118,1989 b$. 
Miller, J. D., and D. V. Kent, Regional trends in the timing of Alleghanian remagnetization in the Appalachians, Geology, 16, 588-591, 1988.

Möller, P., P. P. Parekh, and H-J. Schneider, The application of $\mathrm{Tb} / \mathrm{Ca}-\mathrm{Tb} / \mathrm{La}$ abundance ratios to problems of fluorspar genesis, Miner. Deposita, 11, 111-116, 1976.

Montgomery, C. W., and W. F. Brace, Micropores in plagioclase, Contrib. Mineral. Petrol., 52, 17-28, 1975.

Moorbath, S., P. N. Taylor, J. L. Orpen, P. Treloar, and J. F. Wilson, First direct radiometric dating of Archaean stromatolitic limestone, Nature, 326, 865-867, 1987.

Morgan, J. W., and G. A. Wandless, Rare earth element distribution in some hydrothermal minerals: Evidence for crystallographic control, Geochim. Cosmochim. Acta, 44, 973-980, 1980.

Morton, J. P., Rb-Sr evidence for punctuated illite/smectite diagenesis in the Oligocene Frio Formation, Texas Gulf Coast, Geol. Soc. Am. Bull., 96, 114-122, $1985 a$.

Morton, J. P., Rb-Sr dating of diagenesis and source age of clays in Upper Devonian black shales of Texas, Geol. Soc. Am. Bull., 96, 1043-1049, $1985 b$.

Nakai, S., A. N. Halliday, S. E. Kesler, and H. D. Jones, Rb-Sr dating of sphalerites and the genesis of Mississippi Valley Type ore deposits, Nature, 346, 354-357, 1990.

Norman, D. K., Analysis of Rb, $\mathrm{Sr}$ and $\mathrm{Sr}$ isotopes in fluid inclusion waters, Trans. Inst. Min. Metall., Sect. B, 87, 34-35, 1978.

Norman, D. I., and G. P. Landis, Source of mineralising components in hydrothermal ore fluids as evidenced by ${ }^{87} \mathrm{Sr}{ }^{\beta 6} \mathrm{Sr}$ and stable isotope data from the Pasto Bueno deposit, Peru, Econ. Geol., 78, 451-465, 1983.

$\mathrm{Ohr}, \mathrm{M}$., and A. N. Halliday, Sm-Nd isotopic equilibration during diagenesis of argillaceous sediments, (abstract), Eos. Trans. $A G U, 71,1716,1990$.

Ohr, M., A. N. Halliday, and D. R. Peacor, Sr and Nd isotopic evidence for punctuated clay diagenesis, Texas Gulf Coast, Earth Planet. Sci. Lett., in press, 1991.

Oliver, J., Fluids expelled tectonically from orogenic belts: Their role in hydrocarbon migration and other geologic phenomena, Geology, 14, 99-102, 1986.

Parnell, J., and I. Swainbank, $\mathrm{Pb}-\mathrm{Pb}$ dating of hydrocarbon migration into a bitumen-bearing ore deposit, North Wales, Geology, 18, 1028-1030, 1990.

Parsons, I., D. C. Rex, P. Guise, and A. N. Halliday, Argon loss by alkali feldspars, Geochim. Cosmochim. Acta, 52, 1097-1112, 1988.

Powers, L. S., H. K. Brueckner, and D. H. Krinsley, Rb-Sr provenance ages from weathered and stream transported quartz grains from the Harney Peak Granite, Black Hills, South Dakota, Geochim. Cosmochim. Acta, 43, 137-146, 1979.

Ravizza, G., and K. K. Turekian, Application of the ${ }^{187} \mathrm{Re} /{ }^{187} \mathrm{Os}$ system to black shale geochronometry, Geochim. Cosmochim. Acta, 53, 3257-3262, 1989.

Rodgers, G. P., and H. D. Holland, Weathering products within microcracks in feldspars, Geology, 7, 278-280, 1979.

Ruiz, J., L. Jones, and W. C. Kelly, Rubidium-strontium dating of ore deposits in Rb-rich host rocks using calcite and other Sr-bearing minerals, Geology, 12, 259-262, 1984.

Schandl, E. S., D. W. Davis, and T. E. Krogh, Are the alteration halos of massive sulfide deposits syngenetic? Evidence from $\mathrm{U}-\mathrm{Pb}$ dating of hydrothermal rutile at the Kidd volcanic center, Abitibi subprovince, Canada, Geology, 18, 505-508, 1990.

Shepherd, T. J., Fluid inclusion Rb-Sr geochronology of mineral deposits, in Geology in the Real World, The Kingsley Dunham Volume, Trans. Inst. Min. Metall., 403-412, 1986.
Shepherd, T. J., and D. P. F. Darbyshire, Fluid inclusion Rb-Sr isochrons for dating mineral deposits, Nature, 290, 578-579, 1981.

Shepherd, T. J., D. P. F. Darbyshire, G. R. Moore, and D. A. Greenwood, Rare earth element and isotopic geochemistry of the North Pennine ore deposits, Bull. Bur. Rech. Geol. Min., 11, 371-377, 1982.

Smith, P. E., and R. M. Farquhar, Direct dating of Phanerozoic sediments by the ${ }^{238} \mathrm{U} /{ }^{206} \mathrm{~Pb}$ method, Nature, $341,518-521$, 1988.

Snee, L. W., J. F. Sutter, and W. C. Kelly. Thermochronology of economic mineral deposits: Dating the stages of mineralization at Panasqueira, Portugal, by high precision ${ }^{40} \mathrm{Ar}-{ }^{39} \mathrm{Ar}$ age spectrum techniques on muscovite, Econ. Geol., 83, 335-354, 1988.

Stuckless, J. S., Uranium and thorium concentrations in Precambrian granites as indicators of a uranium province in central Wyoming, Contrib. Geol., 17, 173-178, 1979.

Sutter, J. F., J. Hartung, and W. C. Kelly, Laser micro-probe argon dating of ore deposits, Geol. Soc. Am. Abstr. Programs, $15,702,1983$.

Sverjensky, D. A., Genesis of Mississippi Valley-type lead-zinc deposits, Ann. Rev. Earth Planet. Sci., 14, 177-199, 1986.

Tucker, R. D., A. Raheim, T. E. Krogh, and F. Corfu, Uraniumlead zircon and titanite ages from the northern portion of the Western Gneiss Region, south-central Norway, Earth Planet. Sci. Lett., 81, 203-211, 1987.

Tumer, G., Hydrothermal fluids and argon isotopes in quartz veins and cherts, Geochim. Cosmochim. Acta, 52, 1443-1448, 1988.

Vance, D., and R. K. O'Nions, Isotopic chronometry of zoned garnets: Growth kinetics and metamorphic histories, Earth Planet Sci. Lett., 97, 227-240, 1990.

Van der Voo, R., Paleomagnetism of North America: The craton, its margins and the Appalachian Belt, Geol. Soc. Am. Mem., 172, 447-470, 1989.

Walker, F. D., Ion microprobe study of intragrain permeability in alkali feldspars, Contrib. Mineral. Petrol., 106, 124-128, 1990.

Walker, R. J., S. B. Shirey, G. N. Hanson, V. Rajamani, and M. F. Horan, $\mathrm{Re}-\mathrm{Os}, \mathrm{Rb}-\mathrm{Sr}$, and $\mathrm{O}$ isotopic systematics of the Archean Kolar Schist Belt, Karnataka, India, Geochim. Cosmochim. Acta, 53, 3005-3013, 1989.

Wisniowiecke, M., R. Van der Voo, C. McCabe, and W. C. Kelly, A Pennsylvanian paleomagnetic pole from the mineralized Late Precambrian Bonne Terre Formation, Southeast Missouri, J. Geophys. Res., 88, 6540-6548, 1983.

Worden, R. H., F. D. L. Walker, I. Parsons, and W. L. Brown, Development of microporosity, diffusion channels and deuteric coarsening in perthitic alkali feldspars, Contrib. Mineral. Petrol., 104, 507-515, 1990.

York, D., and C. M. Hall, Continuous laser-probe thin section chrontouring of sediments, Terra Cognita, 6, 117, 1986.

York, D., A. Masliwec, P. Kuybida, J. A. Hanes, C. M. Hall, W. J. Kenyon, E. T. C. Spooner, and S. D. Scoth, ${ }^{40} \mathrm{Ar}-{ }^{39} \mathrm{Ar}$ dating of pyrite, Nature, 300, 52-53, 1982.

Zeitler, P. K., B. Barreiro, C. P. Chamberlain, and D. Rumble III, Ion microprobe dating of zircon from quartz-graphite veins at the Bristol, New Hampshire, metamorphic hot spot, Geology, 18, 626-629, 1990.

J. T. Chesley, C. P. DeWolf, A. N. Halliday, K. Mezger, S. Nakai, and M. Ohr, Department of Geological Sciences, University of Michigan, Ann Arbor, MI 48109. 